\title{
Proximate composition and aroma quality of five aromatic upland-rice accessions from Sumba Barat Daya District, East Nusa Tenggara Province, Indonesia
}

\author{
I.G.B. ADWITA ARSA", H.J.D. LALEL, R. POLLO \\ Department of Agrotechnology, Faculty of Agriculture, Universitas Nusa Cendana. Jl. Adisucipto, Penfui, Kupang 85001, East Nusa Tenggara, \\ Indonesia. Tel./fax.: +62-380-881085, `email: adwita_arsa@staf.undana.ac.id \\ Manuscript received: 5 September 2019. Revision accepted: 16 October 2019
}

\begin{abstract}
Arsa IGBA, Lalel HJD, Pollo R. 2019. Proximate composition and aroma quality of five aromatic upland-rice accessions from Sumba Barat Daya District, East Nusa Tenggara Province, Indonesia. Trop Drylands 3: 35-40. Dryland agriculture system has the potentials to produce aromatic rice despite the low productivity. Dryland regions, such as in Sumba Island, Indonesia have genetic resources of aromatic rice lines, although the information regarding such lines is less explored. This research aimed to know the proximate composition and aroma quality of five aromatic upland-rice accessions from Sumba Barat Daya District, East Nusa Tenggara Province, and their correlation with the physical and chemical properties of the soil taken from the planting area of each accession. The five accessions studied were ACC-04, ACC-05, ACC-06, ACC-08, and ACC-09. Proximate composition analysis of each aromatic upland-rice accession was carried out by method recommended by AOAC (1970) to determine the water content, ash, fat, protein, carbohydrate, starch, amylose, and amylopectin contents of the rice. The rice aroma score was determined by a sensory test. Analysis of physical and chemical characters of soil was done on a composited soil taken from planting area of each aromatic upland-rice accession at the time of harvest. The results showed that ACC- 04 had the highest ash content, AC- 09 had the highest fat content and protein contents, and ACC-06 showed the highest carbohydrate content. Furthermore, the best aroma quality of rice-based on aroma score and 2-AP content was shown by, respectively, ACC-06 and ACC-05. There was no significant correlation between proximate composition and aroma quality with any component of environmental factors, thus, they were more likely to be determined by genetic factors.
\end{abstract}

Keywords: 2-AP content, accessions, aromatic, proximate, upland rice

\section{INTRODUCTION}

Development of food crops in East Nusa Tenggara (ENT) Province, Indonesia is mainly based on dryland farming system, which relies mainly on rainfall as the main water source. The potential dryland area in ENT is quite extensive but most of the areas have not been cultivated. Besides corn, rice is the second most cultivated crop in this dryland region. The total cultivated area of upland rice in ENT is less than $80,000 \mathrm{ha}$, or still far below the potential dryland area in the province. Sumba Barat Daya (SBD) District is one of the upland rice production centers in ENT Province. The harvested area of upland rice in the district during 2002-2006 period ranged from 8,955 - 13,464 ha with total production of $17,870-26,39$ tons or average productivity of $1.855-1.996 \mathrm{t} \mathrm{ha}^{-1}$ (Dinas Pertanian TPH NTT 2006).

The upland rice planting areas in SBD District are spread in several sub-districts, with the most extensive production centers are North Kodi and West Wewewa subdistricts. The interest of farmers to grow upland rice is driven by the availability of extensive dryland areas and high market demand for local upland rice from this district. The most popular local variety for the local people of SBD District and also the people of ENT, in general, is the aromatic rice variety, known as the Pare Wangi.
Efforts for extensive development of this rice variety are still facing many obstacles. One of them is unoptimal expression of the superiority of its fragrant aroma and fluffiness, and the quality of the rice when it is planted outside its specific location area. In an optimum growing location, the productivity of Pare Wangi variety can reach $3.0 \mathrm{t} \mathrm{ha}^{-1}$ but its yield in North Kodi sub-district only reached less than $2.0 \mathrm{t} \mathrm{ha}^{-1}$. Although the productivity in Kodi sub-district is just a moderate level, the aroma quality and taste of the rice from this sub-district is quite high. On the other hand, the aroma and taste of upland rice harvested outside North Kodi sub-district are not as good as upland rice harvested from Kodi sub-district (Arsa et al. 2016).

Aroma quality of aromatic upland rice may be related to genetic and environmental factors, and interactions of these two factors. Non-aromatic upland rice varieties planted near coastal areas produced no fragrant scent. Similarly, aromatic upland rice varieties also show changes in the quality and taste of rice when planted in other locations far from coastal areas. This indicated that edaphic factors are determinant factors for the expression of aroma quality of upland rice varieties. This is in line with Champagne (2008), which stated that fertilization or addition of nutrients to the soil is one of the environmental factors that determine the quality of rice aroma. Jin-xia et al. (2009) reported that the strongest fragrance was obtained in the treatment of $\mathrm{ZnCl}_{2}$ at a dose of $80-120 \mathrm{mg} \mathrm{kg}^{-1}$ of soil. 
Jiang et al. (2007) reported that $\mathrm{Zn}$ content affected the protein content of rice, and the protein content of rice has a negative correlation with aroma (Champagne 2008). The main compound that has been widely reported contributing to the quality of fragrant scents is 2-acetyl-1-pyrroline (2AP) (Buttery et al. 1982; Jezussek et al. 2002). In the case of the plant facing drought stress, and metabolic processes of the plant is disturbed, volatile flavor compounds will be formed, including 2-AP compounds (Champagne 2008). Thus, the drought factor can trigger an increase in aroma, but the yield of the plant may decrease. Differences in genetic factors are likely to differently affect the quality of rice aroma and rice nutrient content in a condition of drought stress or other stresses related to soil conditions, both physical and chemical properties of the soil.

The opportunity for obtaining fragrant upland rice varieties with good aroma quality and nutrient content is supported by the evaluation of several upland rice accessions collected from several regions in Sumba Barat Daya (SBD) District. Of the 10 upland rice accessions evaluated for the quality of their aroma, five local upland rice accessions showed quite a strong fragrance, namely ACC-04, ACC-05, ACC-06, ACC-08, and ACC-09 (Arsa et al. 2018). In addition to their aroma quality, the proximate composition of these rice accessions needs also to be determined. Since the five accessions were collected from various regions with different growing conditions in Sumba Barat Daya (SBD) District, it is also necessary to understand the relationships between the growing environmental factors and the aroma quality and proximate content of these rice accessions.

This study aimed to determine the proximate composition and aroma quality of five accessions of aromatic upland rice collected from several regions in Sumba Barat Daya (SBD) District, East Nusa Tenggara Province and their relationships with environmental factors.

\section{MATERIALS AND METHODS}

\section{Research location and materials}

The research materials used in this study, i.e. upland rice grains and soil samples, were collected in Sumba Barat Daya (SBD) District, East Nusa Tenggara Province. Analysis of soil properties was carried out in Soil Laboratory of Faculty of Agriculture, and analysis of grain proximate and aroma score of rice was carried out in Biosains Laboratory, Universitas Nusa Cendana. Grains of five accessions of aromatic upland rice were used in this study, i.e., ACC-04300518, ACC-05300518, ACC06300518, ACC-08300518, and ACC-09310518. From here forward, these five rice accessions were coded as, respectively, ACC-04, ACC-05, ACC-06, ACC-08, and ACC-09. The first four accessions were collected in farmer's upland rice fields in Kodi Balaghar Sub-District (i.e. ACC-04 and ACC-05 were collected in Waiha Village, ACC-06 was from Panenggo Ede Village and ACC-08 was from Kahale Village), while the ACC-09 was collected from farmer's field in the Kendu Wela Village, North Kodi sub-district. The sampling of grains (whole, sun-dried grain) of all accessions was taken in May 2018.

A composite soil sampling was also carried out by digging and collecting soil from rice field of each aromatic upland rice accession. These soil samples were analyzed for its physical properties (soil moisture content and soil texture) and chemical properties (organic carbon content (C-org), nitrogen $(\mathrm{N})$, phosphorus $(\mathrm{P})$, potassium $(\mathrm{K})$, sodium $(\mathrm{Na})$, and zinc $(\mathrm{Zn}))$.

\section{Proximate, starch, amylose and amylopectin analysis}

The proximate content was determined based on the method recommended by AOAC (1970), including water content, ash/minerals, fat, protein, and carbohydrate contents. Water content $(\%)$ was measured by an oven method, ash/mineral content (\%) was measured by a gravimetric method and ignition in the furnace, fat content was measured by Soxhlet Extraction method, crude protein content $(\%)$ was measured by Micro-Kjeldahl method, and total carbohydrate $(\%)$ was measured by the Difference Method. These methods were also used in previous studies by Arsa et al. (2016) and Murningsih et al. (2019). The nutrient content of rice measured was starch, amylose, and amylopectin levels.

Starch measurement was carried out by using the AOAC method (1970). The working principle used was extracting the perchloric acid and added with anthrone, then was heated at a temperature of $100{ }^{\circ} \mathrm{C}$ for 12 minutes, and cooled. After cooling down, the absorbance was measured at $607 \mathrm{~nm}$ and compared to the standard.

Amylose was measured using the IRRI method (Juliano 1971). The method used a $95 \%$ ethanol reagent and $\mathrm{NaOH}$ $1 \mathrm{~N} .100 \mathrm{mg}$ of flour was put into a test tube and then added with the two reagents, $1 \mathrm{~mL}$ and $9 \mathrm{~mL}$, respectively. The mixture was heated in boiling water for about 10 minutes until a gel was formed, and the gel was transferred into a $100 \mathrm{~mL}$ measuring flask, then was shaken and added with water until the anchovy marks. $5 \mathrm{~mL}$ of the solution was pipetted and put into a $100 \mathrm{~mL}$ measuring flask. Then, the pipetted solution was added with $1 \mathrm{~mL}$ of $1 \mathrm{~N}$ acetic acid and $2 \mathrm{~mL}$ of iodine solution, and was added with water until the tarpaulin was shaken, and left for 20 minutes.

Furthermore, the intensity of the color formed was measured with a spectrophotometer at a wavelength of 625 $\mathrm{nm}$. Amylose content in the sample was calculated using the standard amylose curve. After amylose content was measured, the amylopectin level could be determined by deducting the amylose content from the starch content.

\section{Quality of rice aroma (organoleptic test)}

The sensory or olfactory organoleptic test was carried out by five trained panelists to assess the aroma and taste of the rice. Five grams of each rice sample was put in a test tube and then added with $15 \mathrm{ml}$ of water and covered with aluminum foil. The test tube was shaken for 10 minutes and then cooked for another 15 minutes. The cooked rice samples were transferred to a petri dish and put in the refrigerator for 20 minutes. The cooled rice was then smelled and chewed by the trained panelist. The score used had an interval of 0 - 4 resembling the aroma criteria, i.e., 
$<0.5=$ not flavorful, $0.5-<1.5=$ weak flavorful, $1.5-<2.5$ $=$ moderate flavorful, $2.5-<3.5=$ flavorful, and a bit strong aroma, and $\geq 3.5=$ strong flavorful.

\section{Data analysis}

Data from the measurement of grain samples in the laboratory were descriptively analyzed. A simple correlation analysis was carried out to know the relationship between the aroma quality and the other rice quality traits with physical and chemical properties of the soil taken from the areas where the rice accessions were grown. The correlation coefficient was calculated using the following formula:

\begin{tabular}{|c|c|c|}
\hline \multirow[b]{3}{*}{ Note: } & \multicolumn{2}{|r|}{$\operatorname{Cov}_{x, y}$} \\
\hline & $r_{x y}$ & ------------- \\
\hline & & \\
\hline & $=$ & Simple correlation of $\mathrm{x}$ and $\mathrm{y}$ \\
\hline $\operatorname{Cov}_{x, y}$ & $=$ & Covariance of $x$ dan $y$ \\
\hline$\sigma^{2} x$ & $=$ & Variety $\mathrm{x}$ \\
\hline
\end{tabular}

\section{RESULTS AND DISCUSSIONS}

\section{Soil physical and chemical properties}

Analysis results of soil physical and chemical properties are presented in Table 1. Textures of soil from aromatic upland rice fields of ACC-04, ACC-05, and ACC-08 were loam sandy while that of rice field of ACC-06 was sandy loam, and ACC-09 was sandy clay loam. Soil texture and rainfall conditions of the rice accession's planting locations were almost similar as they are located close to each other in the same sub-district, thus, the soil water content at harvest time was not much different among the planting locations of rice accessions ACC-04, ACC- 05, ACC-06, and ACC-08. Soil texture of the planting location of AAC09 with a higher loam content contained higher soil moisture $(28.40 \%)$ as compared to those of the other four accessions' planting locations.

Organic-C content of soil taken from the rice planting locations (Table 1) are in accordance with the finding of Rosmarkam and Yuwono (2002). The planting location of aromatic upland rice had high organic-C content (ACC-04, ACC-05, and ACC-09), and a very high C-organic content for ACC-06 (4.81\%) and ACC-08 (6.48\%) planting areas. Furthermore, the total $\mathrm{N}$ content of the soil was classified as low for ACC-04 (0.14\%) and ACC-05 (0.14\%) planting locations, and was moderate for ACC-06 (0.22\%), ACC-08 $(0.32 \%)$ and ACC-09 (0.29\%) planting locations. Soil K and $\mathrm{P}$ contents of all planting locations were classified low, and $\mathrm{Na}$ and $\mathrm{Zn}$ contents in all planting locations were relatively moderate (Table 1 ).
Table 1 also shows a significant difference in the physical properties of soil, both in soil water content and soil texture indicated by the planting location of the aromatic upland rice accession ACC-09 as compared to those of other rice accessions. The difference in soil chemical properties was seen in total $\mathrm{N}$ content of the soil, where the total $\mathrm{N}$ content of soil of ACC-04 and ACC-05 planting locations was classified as low while that of ACC06, ACC-08, and ACC-09 planting locations was of moderate level. Soil Na content at ACC-06 and ACC-08 planting locations tended to be higher than planting locations of other accessions, while other nutrient levels were relatively similar between planting locations of each aromatic upland rice accession.

\section{Proximate composition starch, amylose, and amylopectin contents}

The proximate composition analysis of five aromatic upland rice accessions from SBD is presented in Table 2. The highest moisture content was shown in ACC-09, and the lowest was in ACC-06. The differences in moisture content of rice were more likely occurred due to differences in the way farmers carried out the sun-drying of the grains. These differences may include the drying time or the intensity of sunlight during the grain drying. High water content is not good for grain storage because it triggers fungal growth (Murningsih et al. 2019). The highest ash content of aromatic upland rice accessions was shown by ACC-04 (3.66\%), and the lowest was found in ACC-09 (0.34\%). It can be said that ACC-04 is the best source of minerals among all observed rice accessions. This is in line with the opinion of Murningsih et al. (2019) that the level of ash content reflects the amount of total mineral content. Although ACC-09 has the lowest ash content, its fat and protein levels were the highest, $1.18 \%$ and $9.20 \%$, respectively. This high fat and protein content indicates that ACC-09 rice is a nutrition-rich staple food. Fat is the highest energy source, while protein plays an important role in tissue growth, maintenance, and the replacement of dead cells (Murningsih et al. 2019). The highest nutritional value of rice is carbohydrates. Accession with the highest carbohydrate level was shown by ACC-06, followed by ACC-05, ACC-09, ACC-08, and ACC-04, respectively (Table 2).

Variations in ash, fat, protein and carbohydrate contents of rice accessions as described above are influenced by growing environmental factors. A study by Wang and Frei (2011) explained that drought stress (including salinity) generally could reduce seed mineral content. Drought stress was reported to reduce the content of $\mathrm{Fe}, \mathrm{Zn}$ and $\mathrm{Cu}$ in corn yields but did increase $\mathrm{Ca}, \mathrm{Mg}, \mathrm{Cu}$ and $\mathrm{Zn}$ concentrations compared to control plants. The inconsistency of the relationship between soil water content (Table 1) and the ash content of rice (Table 2) was likely influenced by the interactions with soil nutrient status in the level of mineral absorption by plant roots. The same opinion was expressed by Wang and Frei (2011). 
Table 1. Physical and chemical characteristics of soils taken from planting locations of all collected aromatic upland rice accessions

\begin{tabular}{|c|c|c|c|c|c|c|c|c|}
\hline \multirow[b]{2}{*}{ Accession } & \multicolumn{8}{|c|}{ Soil physical and chemical properties } \\
\hline & Texture & $\begin{array}{l}\text { SWC } \\
(\%)+\end{array}$ & $\begin{array}{c}\text { Organic- } \\
\text { C (\%) }\end{array}$ & $\begin{array}{c}\text { Total-N } \\
(\%)\end{array}$ & $\begin{array}{c}\mathrm{K}(\mathrm{me} / \\
100 \mathrm{~g}\end{array}$ & $\mathbf{P}(\mathbf{p p m})$ & $\begin{array}{c}\mathrm{Na}(\mathrm{me} / \\
100 \mathrm{~g})\end{array}$ & Zn (ppm) \\
\hline ACC-04 & Loam sandy & 8.0 & 3.2 & 0.1 & 0.8 & 50.8 & 0.7 & 52.4 \\
\hline ACC-05 & Loam sandy & 7.6 & 3.2 & 0.1 & 0.8 & $51 ., 8$ & 0.7 & 53.4 \\
\hline ACC-06 & Sandy loam & 7.6 & 4.8 & 0.2 & 0.8 & 50.4 & 1.0 & 52.3 \\
\hline ACC-08 & Loam sandy & 8.8 & 6.5 & 0.3 & 0.9 & 49.4 & 1.4 & 51.6 \\
\hline ACC-09 & Sandy clay loam & 23.2 & 3.2 & 0.3 & 1.0 & 60.0 & 0.7 & 61.7 \\
\hline
\end{tabular}

Note: +: Soil Water Content at harvesting stage of the rice

Table 2. Proximate composition of five aromatic upland rice accessions from Sumba Barat Daya, East Nusa Tenggara, Indonesia

\begin{tabular}{lccccc}
\hline Rice accessions & Water content $(\boldsymbol{\%})$ & Ash $(\boldsymbol{\%})$ & Fat $(\boldsymbol{\%})$ & Protein $(\boldsymbol{\%})$ & Carbohydrate $(\boldsymbol{\%})$ \\
\hline ACC-04 & $12.8 \pm 0.12$ & $3.7 \pm 0.40$ & $1.1 \pm 0.54$ & $7.8 \pm 0.14$ & $74.7 \pm 6.65$ \\
ACC-05 & $12.7 \pm 0.28$ & $0.4 \pm 0.08$ & $0.4 \pm 0.12$ & $5.8 \pm 0.42$ & $80.6 \pm 1.98$ \\
ACC-06 & $11.0 \pm 0.72$ & $0.7 \pm 0.21$ & $0.6 \pm 0.24$ & $5.9 \pm 0.28$ & $81.8 \pm 0.99$ \\
ACC-08 & $12.7 \pm 0.38$ & $1.1 \pm 0.07$ & $1.2 \pm 0.17$ & $5.6 \pm 0.28$ & $79.4 \pm 0.99$ \\
ACC-09 & $13.3 \pm 0.74$ & $0.3 \pm 0.07$ & $1.2 \pm 0.31$ & $9.2 \pm 0.57$ & $76.0 \pm 2.83$ \\
\hline
\end{tabular}

Note: Data were means \pm standard deviation of 2 replications

Table 3. Starch, amylose and amylopectin levels of local upland rice accession in Sumba Barat Daya, East Nusa Tenggara, Indonesia

\begin{tabular}{lllc}
\hline Accessions & Starch $(\boldsymbol{\%})$ & Amylose $(\boldsymbol{\%})$ & $\begin{array}{c}\text { Amylopectin } \\
(\boldsymbol{\%})\end{array}$ \\
\hline ACC-04 & $74.2 \pm 3.11$ & $23.9 \pm 3.39$ & $50.3 \pm 2.12$ \\
ACC-05 & $72.9 \pm 6.22$ & $24.4 \pm 2.40$ & $48.5 \pm 1.98$ \\
ACC-06 & $77.1 \pm 4.38$ & $22.5 \pm 1.27$ & $54.6 \pm 1.13$ \\
ACC-08 & $74.3 \pm 3.25$ & $27.2 \pm 2.83$ & $47.1 \pm 0.85$ \\
ACC-09 & $75.1 \pm 2.12$ & $23.2 \pm 3.39$ & $51.9 \pm 2.55$ \\
\hline
\end{tabular}

Note: Data were meant \pm standard deviation of 2 replications

The soil water level as an indicator of the drought stress is also reported to affect the nutrient levels in seed yields, such as: fat, protein, and carbohydrates (Wang and Frei 2011). The drought is generally reported to induce an increase in total protein concentration in plant seed organs. The length of drought stress is explained as an important factor that determines the effect of drought stress on protein concentration in plant yields. The concentration of fat and starch produced by plants was reported to decrease due to drought stress, but inconsistencies were found in sugar concentration. In line with these results, Pandey et al. (2014) reported that amylose levels would also decrease due to drought stress. This was also found in a study by Arsa (2016), which showed that a decrease in soil water content caused a decrease in upland rice amylose content of Pare Wangi variety.

In this study, the relationship between soil water content did not show a consistent effect on fat and carbohydrate levels (Table 1), but there was a tendency of soil water content to influence the rice protein levels enhancement (Table 2). Soil moisture content also did not show a consistent effect on starch, amylose, and amylopectin levels (Table 3). The effect of soil water content on the nutritional value of rice, fat, carbohydrate, protein, starch, amylose, and amylopectin was shown by simple correlation coefficient values (Table 5). Environmental variations during the growth of aromatic upland rice as indicated by variations in soil chemical properties, such as: $\mathrm{C}$-org, N, P, K, Na, and Zn (Table 1) likely affected the consistency of soil water content and nutrient content of rice. Another factor that might influence the rice nutrient levels to soil water content is the genetic factors difference of aromatic upland rice accession. In addition to soil water content, high soil nutrient levels, especially N, P, K and Zn, and low Na content caused ACC-09 to grow more optimal than others. This determines the factor influencing the high levels of rice fat and protein from ACC-09, although it did not look consistent for ACC04 which had lower soil $\mathrm{N}$ levels compared to ACC-06. A consistent relationship pattern was not seen in the results of rice carbohydrates on growing environmental factors. Accessions that showed the highest carbohydrate content values are shown in ACC-06, followed by ACC-05, ACC08, ACC-09, and ACC-04 (Table 3).

\section{Aroma quality}

Aromatic scores of five accessions of aromatic upland rice ranged from 1.8 to 3.4 (Table 4 ). The highest aromatic score was shown in ACC-06, while ACC-09 showed the lowest aromatic score. The aroma score was not always consistent with the level of 2AP of rice for each accession of evaluated aromatic upland rice. Accession with a high scent value of rice is reported to have high levels of $2 \mathrm{AP}$ and vice versa with a low aromatic score, because the levels of 2AP compounds were the main compounds that contributed to the aroma of rice (Buttery et al. 1982; Jezussek et al. 2002 ). Levels of 2AP compounds reported producing a fragrant aroma of rice were quite stable if the level of $2 \mathrm{AP}$ reaches at least $7.0 \mathrm{ppb}$. 
Table 5. Correlation between soil physical and chemical properties with proximate content, starch, amylose, amylopectin, and aroma quality of rice

\begin{tabular}{lccccccccc}
\hline $\mathbf{r}$ & Ka Rice & Ash & Fat & Pro. & Crb. & Starch & Amyl. & Amlp. & Arm \\
\hline SWC & $0.54^{\text {ns }}$ & $-0.35^{\text {ns }}$ & $0.47^{\text {ns }}$ & $0.82^{*}$ & $-0.48^{\text {ns }}$ & $0.13^{\text {ns }}$ & $-0.27^{\text {ns }}$ & $0.23^{\text {ns }}$ & $-0.77^{\text {ns }}$ \\
$\mathrm{N}$ & $0.14^{\text {ns }}$ & $-0.44^{\text {ns }}$ & $0.58^{\text {ns }}$ & $0.08^{\text {ns }}$ & $0.04^{\text {ns }}$ & $0.34^{\text {ns }}$ & $0.40^{\text {ns }}$ & $-0.07^{\text {ns }}$ & $-0.68^{\text {ns }}$ \\
K & $0.53^{\text {ns }}$ & $-0.37^{\text {ns }}$ & $0.45^{\text {ns }}$ & $0.81^{*}$ & $-0.46^{\text {ns }}$ & $0.13^{\text {ns }}$ & $-0.28^{\text {ns }}$ & $0.24^{\text {ns }}$ & $-0.77^{\text {ns }}$ \\
P & $0.52^{\text {ns }}$ & $-0.37^{\text {ns }}$ & $0.27^{\text {ns }}$ & $0.84^{*}$ & $-0.45^{\text {ns }}$ & $0.05^{\text {ns }}$ & $-0.43^{\text {ns }}$ & $0.29^{\text {ns }}$ & $-0.66^{\text {ns }}$ \\
Na & $-0.31^{\text {ns }}$ & $-0.16^{\text {ns }}$ & $0.24^{\text {ns }}$ & $-0.62^{\text {ns }}$ & $0.45^{\text {ns }}$ & $0.25^{\text {ns }}$ & $0.68^{\text {ns }}$ & $-0.29^{\text {ns }}$ & $-0.07^{\text {ns }}$ \\
Zn & $0.52^{\text {ns }}$ & $-0.39^{\text {ns }}$ & $0.29^{\text {ns }}$ & $0.83^{*}$ & $-0.43^{\text {ns }}$ & $0.07^{\text {ns }}$ & $-0.39^{\text {ns }}$ & $0.28^{\text {ns }}$ & $-0.69^{\text {ns }}$ \\
\hline
\end{tabular}

Note: KA Rice $=$ moisture content of rice $(\%)$; Ash $=$ ash content of rice $(\%)$; Fat $=$ fat content of rice $(\%)$; Crb $=$ level of rice carbohydrate $(\%)$; starch = rice starch content $(\%)$; Amyl = Amylose content of rice (\%); Aml = rice amylopectin level; Arm = score of aroma of rice; $\mathrm{ns}=$ non significant, $*=$ significant at $\mathrm{p}$-value $\leq 0.05$.

Table 4. Aroma scores and levels of $2 \mathrm{AP}$ local upland rice accession from Sumba Barat Daya, East Nusa Tenggara, Indonesia

\begin{tabular}{lc}
\hline Accessions & Aroma score \\
\hline ACC-04 & $3.0 \pm 0.17$ \\
ACC-05 & $2.8 \pm 0.14$ \\
ACC-06 & $3.4 \pm 0.14$ \\
ACC-08 & $2.2 \pm 0.12$ \\
ACC-09 & $1.8 \pm 0.16$ \\
\hline
\end{tabular}

Note: scent score $<0.5=$ not flavorful; $0.5-<1.5=$ weak flavorful; $1.5-<2.5$ = moderate flavorful; $2.5-<3.5$ = flavorful, and $\geq 3.5=$ strong flavorful.

The mechanism to increase the levels of rice $2 \mathrm{AP}$ was generally associated with increased levels of proline amino acid in plant tissues triggered by drought and salinity stresses (Yoshihashi 2005). Several research reported that an increase in 2AP levels is associated with increasing uptake of soil nutrients such as $\mathrm{N}$ (Yang et al. 2012), P (Rohilla et al. 2000), and Zn (Jin-xia et al. 2009). In this study, there was no significant correlation between aroma score with soil water content (SWC) and soil chemical properties, especially N, P, K, Na and Zn levels (Table 5). Thus, the difference in the aroma quality among aromatic upland rice accessions was more likely determined by the differences in genetic factors. In the study of Arsa et al. (2016), correlation between 2AP level and soil moisture in upland rice of Pare Wangi variety showed a quadratic response, which means that an increase of 2AP levels of rice will reach a maximum at optimum soil moisture, and vice versa, the $2 \mathrm{AP}$ level will decrease along with the decrease of soil moisture (increase of drought stress). This is in line with the negative correlation value of the aroma score of rice with soil moisture content (Table 5). A negative correlation value was found between the aroma of rice with $\mathrm{N}, \mathrm{P}$, and $\mathrm{K}$ soil levels. This occurs through the mechanism of proline amino acid formation, which decreased at higher levels of soil N, P, and K contents. This can occur in soil moisture levels that have already passed the optimum soil moisture. The above findings explained that an increase in absorption of soil $\mathrm{N}, \mathrm{P}, \mathrm{K}$ elements would increase the level of rice 2AP rice if soil moisture is moderate enough to support the uptake of soil N, P, K elements and other soil nutrition elements by plant roots.
Furthermore, the availability of plant tissue N, P, and K levels in a balanced amount, including micronutrients, will spur the proline amino acid biosynthesis process into a $2 \mathrm{AP}$ compound. Ram et al. (2013) stated that the macro and micronutrient balance significantly improved the quality of the rice aroma.

In conclusion, the study results revealed that the five aromatic upland rice accessions have a fairly variation in proximate content. ACC-04 rice produced the highest ash content, while ACC-09 rice had the highest fat and protein contents, and ACC-06 produced the highest carbohydrate content. The best rice aroma quality based on the aroma score was shown by, respectively, ACC-06 and ACC-05. There was no significant correlation between each of the proximate levels and aroma quality of the aromatic upland rice accessions with environmental factors; thus, the differences in proximate level and aroma quality among the rice accessions were more likely determined by the genetic factor.

\section{ACKNOWLEDGEMENTS}

The author would like to thank the Director of Research and Community Service, the Directorate General of Higher Education, the Ministry of Research, Technology and Higher Education for providing the research funding through 2018 Penelitian Dasar Unggulan Perguruan Tinggi (Contract Number: 83/UN15.19/LT/2018).

\section{REFERENCES}

AOAC. 1970. Official Methods of Analysis (11th ed.). Association of Official Analytical Chemists, Washington DC.

Arsa IGBA. 2016. Kualitas Aroma dan Hasil Padi Gogo Aromatik Varietas Pare Wangi di Lahan Kering Sumba Barat Daya, NTT. [Disertasi]. Program Pascasarjana, Fakultas Pertanian, Universitas Brawijaya, Malang. [Indonesian]

Arsa IGBA, Ariffin, Aini N, Lalel HJD. 2016. Evaluation of grain yield and aroma of upland rice (pare wangi var.) as response to soil moisture and salinity. Curr Agric Res 4 (1). DOI: 10.12944/CARJ.4.1.03

Arsa IGBA, Lalel HJD, Pollo R. 2018. Evaluasi Kualitas Aroma dan Kualitas Beras Varietas Lokal Padi Gogo asal Sumba Barat Daya, NTT. Laporan PDUPT. Lembaga Penelitian dan Pengabdian, Universitas Nusa Cendana, Kupang. [Indonesian] 
Buttery RG, Ling LC, Juliano BO. 1982. 2-Acetyl-1-pyrroline: an important aroma component of cooked rice. Chem Ind (Lond) 12 958-959.

Champagne ET. 2008. Rice aroma and flavor: A literature review. Cereal Chem 85 (4) : 445-454. DOI: 10.1094/CCHEM-85-4-0445

Dinas Pertanian TPH. 2006. Keadaan Areal Tanam, Panen, Produktivitas dan Produksi Padi dan Palawija Tahun 2005. Dinas Pertanian TPH Provinsi NTT, Kupang. [Indonesian]

Jezussek M, Juliano BO, Schieberle P. 2002. Comparison of key aroma compounds in cooked brown rice varieties based on aroma extract dilution analyses. J Agric Food Chem 50: 1101-1105. DOI: 10.1021/jf0108720

Jiang HM, Yang JC, Zhang JF. 2007. Effects of external phosphorus on the cell ultrastructure and the chlorophyll content of maize under cadmium and zinc stress. Environ Pollut 147: 750-756. DOI 10.1016/j.envpol.2006.09.006

Huang JX, Xiao D, Duan MY, Tian H, Li GX, Zhong KY, Tang XR 2009. Effects of different applications of $\mathrm{ZnCl}_{2}$ on the yield and aroma content of aromatic rice. Acta Agriculturae Boreali-Sinica 23 (S2): 290-292.

Juliano BO. 1971. A Simplified assay for milled-rice amylase. Cereal Sci Today 16: 334-360.

Murningsih T, Yulita KS, Bora CY, Arsa IGBA. 2019. Kandungan proksimat dan mineral jagung varietas lokal (tunu'ana') dari Nusa
Tenggara Timur. Pros Sem Nas Masy Biodiv Indon 5 (1): 107-111. DOI: $10.13057 / \mathrm{psnmbi} / \mathrm{m} 050120$. [Indonesian]

Pandey A, Kumar A, Pandy DS, Thongbam PD. 2014. Rice quality under water stress. Indian J Adv Plant Res 1 (2): 23-26.

Ram US, Srivastava VK, Hemantaranjan A, Sen A, Singh RK, Bohra JS, Shukla U. 2013. Effect of Zn, Fe, and FYM application on growth, yield, and nutrient content of rice. Oryza 50 (4): 351-357.

Rohilla R, Singh VP, Singh US, Singh RK, Khush GS. 2000. Crop Husbandry and Environmental Factors Affecting Aroma and Other Quality Traits. In: Singh RK, Singh US, Khush GS (eds.). Aromatic Rice. Oxford \& IBH Publishing Co. Pvt. Ltd., New Delhi.

Rosmarkam A, Yuwono NW. 2002. The Science of Soil Fertility. Kanisius, Yogyakarta. [Indonesian]

Wang Y, Frei M. 2011. The impact of abiotic environmental stresses on crop quality. Agric Ecosyst Environ 141: 271-286. DOI: 10.1016/j.agee.2011.03.017

Yang S, Zou Y, Liang Y, Xia B, Liu S, Ibrahim Md, Li D, Li Y, Chen L, Zeng Y, Liu L, Chen Y, Li P, Zhu J. 2012. Role of soil total nitrogen in aroma synthesis of traditional regional aromatic rice in China. Field Crops Res 125: 151-160. DOI: 10.1016/j.fcr.2011.09.002

Yoshihashi T. 2005. Does drought condition induce the aroma quality of aromatic rice? Food Science and Technology Division, JIRCAS. JIRCAS Newsletter No. 43 June 2005 